COHEN, JACK. 1969. Why so many sperms? An essay on the arithmetic of reproduction. Sci. Prog., Oxf., 57, 23-41.

COHEN, JACK. 1971. Comparative physiology of gamete populations. Advances in Comp. Physiol. Biochem., 4, 268-380.

DATTA, M. 1970. Re-investigation of meiosis in the male goat, Capra hircus. Linn. Cytologia, $35,344-353$.

eliasson, K., GUSTAVsson, 1., hULTEN, M., AND LINSTEN, J. 1967. The meiotic chromosomes of the male dog. Hereditas, 58, 135-135.

eVans, H. J. 1968. Personal communication.

Fellous, M., AND DAUsset, J. 1970. Probable haploid expression of HL-A antigens on human spermatozoan. Nature, 225, 191-193.

FORD, C. E. 1972. Gross genome unbalance in mouse spermatozoa: does it influence the capacity to fertilize? In Edinburgh Symposium on the Genetics of the Spermato zoon (ed. R. A. Beatty and Salome Gluecksohn-Waelsch), 359-369. Published by University of Edinburgh.

LONGWELl, A. C., stiles, s. s., AND smith, D. G. 1967. Chromosome complement of the American oyster Crassostrea virginica as seen in meiotic and cleaving eggs. Can. F. Genet. Cytol., 9, 845-856.

LONGWELL, A. C., AND stiles, s. s. 1968. Fertilisation and Completion of Meiosis in Spawned Eggs of the American oyster (Crassostrea virginica Emelin). Caryologia, 21, 65-73.

MAGNI, G. E., AND SORA, s. 1969. Relationships between recombination and mutation. In Mutation as a Cellular Process (ed. G. E. W. Wolstenholme and M. O'Connor), 186-198. Churchill, London.

OLDFIRLD, G. N., NEWELL, I. M., AND REED, D. K. 1972. Insemination of protogynes of Aculus cornutus from spermatophores and description of the sperm cell. Ann. Ent. Soc. Amer., 65, 1080-1084.

ROBINson, R. 1959. Genetics of the domestic cat. Bibliographica Genetica, 18, 273-355.

WhIrehouse, H. L. K. 1970. The mechanism of genetic recombination. Biol. Rev., 45, 265315.

wILKEs, A. 1965. Sperm transfer and utilization by the arrhenotokous wasp Dahlbominus fuscipennis. (Zett.) (Hymenoptera, Eulophidae). Can. Entomol., 97, 647-657.

\title{
GENETICAL VARIATION FOR ENZYME ACTIVITY IN A POPULATION OF DROSOPHILA MELANOGASTER
}

\section{EXTENT OF THE VARIATION FOR ALCOHOL DEHYDROGENASE ACTIVITY}

\author{
A. J. BIRLEY and B. W. BARNES \\ Deportment of Genetics, University of Birminghom, P.O. Box 363, \\ Birminghom B15 2TT, England
}

Received 25.vii.73

\begin{abstract}
SUMMARY
The variation of alcohol dehydrogenase specific activity in a sample of inbred lines derived from a population of Drosophila melanogaster has been investigated. The results demonstrated the existence of extensive genetical variation for activity which, in part, was not detected electrophoretically. The narrow heritability of individuals in the population was estimated as 20.6 per cent.
\end{abstract}

\section{InTRODUGTION}

THE evidence that has accumulated from the many electrophoretic surveys of proteins leaves no doubt that considerable genetic polymorphism exists within natural populations of many species (Harris, 1966, 1969; Hubby and 
Lewontin, 1966; Lewontin and Hubby, 1966; Selander and Yang, 1969; Ayala and Powell, 1972). However, it has been suggested that perhaps only one-third of mutations produce molecular changes which can be detected electrophoretically (Harris, 1969, 1971).

In a number of cases, quantitative differences in the activity of the electrophoretically distinct products of the common alleles have been demonstrated (Harris, 1966, 1971; Gibson and Miklovich, 1971). Variation in specific activity may also result from some of the mutations of the structural gene which do not alter the molecular charge of the protein and hence are undetected electrophoretically. In addition, differences in activity may be determined by variation at loci quite separate from the structural gene. This has recently been demonstrated for the alcohol dehydrogenase locus in Drosophila melanogaster by Ward and Hebert (1972).

The purpose of this study is to determine the extent of the genetical variation for specific activity of alcohol dehydrogenase in a population of Drosophila melanogaster.

\section{MATERIALS AND METHODS}

The population used in this study, Texas, originated from a sample of inseminated females caught at Austin, Texas in 1965. The population was subsequently maintained in a population cage; further details are given by Barnes and Kearsey (1970). A set of 19 inbred lines was derived by sibmating for 42 generations the progeny of single pair matings from this population.

In order to estimate the the allele frequency at the Adh locus a sample of eggs was collected from the cage and raised at low density; from the resulting progeny 250 females were selected at random and assayed by starch gel electrophoresis. The gel and electrode buffers are as described by Poulik (1957). An 11 per cent. starch (Connaught Medical Research Laboratories) gel was used. After electrophoresis the gel was stained for alcohol dehydrogenase by the method described by Ayala et al. (1972).

Measurements of alcohol dehydrogenase specific activity were made on single virgin female flies raised at $25^{\circ} \mathrm{C}$. and aged for 5 days after eclosion. Homogenates were prepared in $0.6 \mathrm{ml}$. of $0.05 \mathrm{M}$ Tris-phosphate buffer $p \mathrm{H}$ 8.5. The homogenates were centrifuged at $3000 \times g$ for 30 minutes at $4^{\circ} \mathrm{C}$. The áctivity of the supernatant was determined by observing the time taken for a change of 0.05 OD units at $340 \mathrm{~m} \mu$ in $1 \mathrm{ml}$. quartz cuvettes at $25^{\circ} \mathrm{C}$. in a SP 1800 Pye Unicam recording spectrophotometer. The reaction mixture contained $2.3 \mathrm{~mm} \beta-\mathrm{NAD}^{+}$and $0.08 \mathrm{~m}$ propan-2-ol. Total protein was measured in each extract using the modified Folin technique described by Miller (1959).

\section{Results}

The results of the electrophoretic assay, given below, show that two Adh alleles are segregating in the population. The allele frequencies are 0.89 for $A d h^{S}$ and 0.11 for $A d h^{F}$.

\begin{tabular}{|c|c|c|c|}
\hline & \multicolumn{3}{|c|}{ Genotype } \\
\hline & $A d h S / A d h S$ & $A d h^{S} / A d h^{F}$ & $\overrightarrow{A d h^{F} / A d h^{F}}$ \\
\hline Number of females & 199 & 47 & 4 \\
\hline
\end{tabular}


Of the 19 inbred lines derived from the Texas population, 17 were homozygous for the slow allele and two were homozygous for the fast allele. These frequencies indicate that there has been very little selection at this locus during the inbreeding programme.

TABLE 1

\begin{tabular}{|c|c|c|c|c|}
\hline \multicolumn{5}{|c|}{ Analysis of variance of the AdhS specific activities } \\
\hline Item & d.f. & M.S. & V.R. & $\mathbf{P}$ \\
\hline Lines & 16 & $21 \cdot 8456$ & $5 \cdot 14$ & $\ll 0.1 \%$ \\
\hline Assays & 3 & $6 \cdot 9221$ & $1 \cdot 63$ & $20 \%$ \\
\hline $\mathrm{L} \times \dot{\mathrm{A}}$ & 48 & $4 \cdot 1330$ & $<1$ & n.s. \\
\hline Duplicates & 68 & $4 \cdot 3287$ & - & - \\
\hline Pooled error & 116 & $4 \cdot 2477$ & - & - \\
\hline
\end{tabular}

TABLE 2

Components of Variation

$\begin{array}{cc}\text { Component } & \begin{array}{c}\text { Percentage of } \\ \text { variation }\end{array} \\ \sigma_{L}^{2} & 33 \cdot 706 \\ \sigma_{A}^{2} & 1 \cdot 205 \\ \sigma_{L}^{2} \times A & 0 \\ \sigma^{2} & 65 \cdot 088\end{array}$

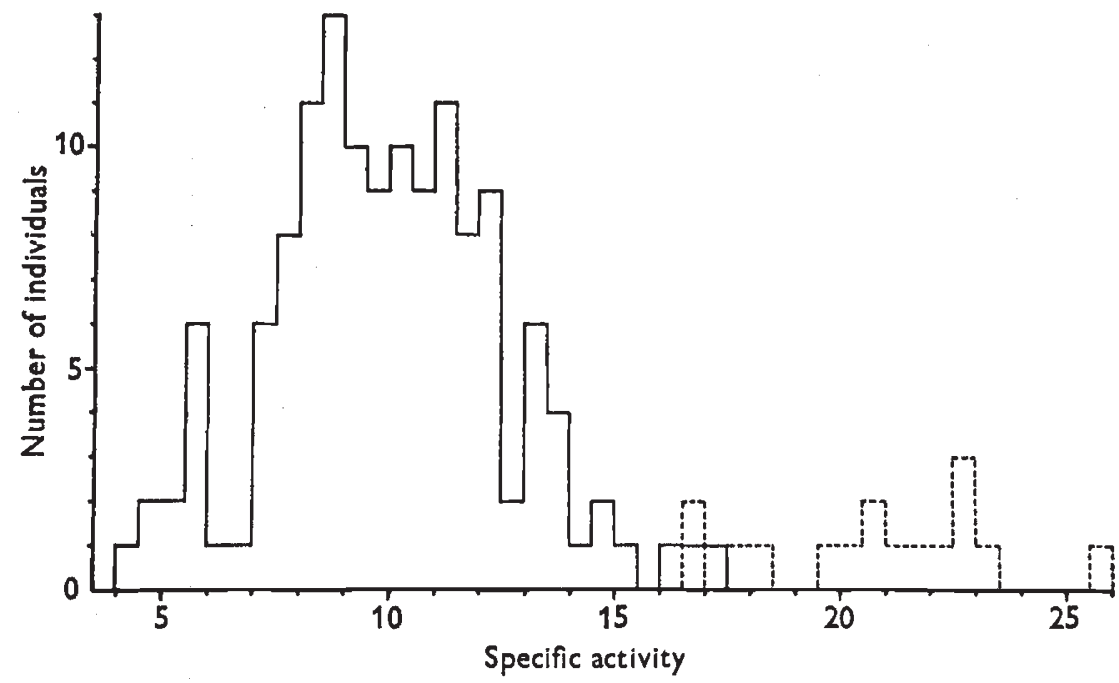

Fic. 1.-Frequency distribution of alcohol dehydrogenase specific activity of individual from lines homozygous $A d h S$ (continuous line) and homozygous $A d h^{F}$ (broken line).

The specific activity of $A d h$ was measured on two individuals from each inbred line on four separate occasions. On each ocasion the whole experiment was set up as a single randomised block. The results of the analysis of the lines homozygous for $A d h^{S}$ are given in table 1.

The analysis shows no interaction between lines and assays, and no difference between assays. The difference between lines is highly significant. The components of variation, assuming both lines and assays are random variables, are given in table 2. 
As a random sample of inbred lines derived from the population was used in this study we may estimate the narrow heritability of individuals in the Texas population as 20.6 per cent.

The range of variation for individual scores over the full set of lines is shown in fig. 1. It is interesting to note that the most active individuals of the slow morph approach the specific activity of the fast morph.

\section{Discussion}

This study has revealed extensive variation in specific activity for $A d h$. This variation was related in part to the two electrophoretically distinguishable alleles segregating in the population. Lines homozygous for $A d h^{F}$ are more active than lines homozygous for $A d h^{S}$, as previously reported (Gibson, 1970; Gibson and Miklovich, 1971). But of more interest is the heritable variation found between the lines homozygous for $A d h^{S}$. The nature of thi variation is being investigated further.

\section{REFERENGES}

AYALA, F. J., AND POWELl, J. R. 1972. Enzyme variability in the Drosophila willistoni group. VI. Levels of polymorphism and the physiological function of enzymes. Biochem. Genet., 7, 331-345.

AYAlA, F. J., POWELl, J. R., TRACEY, M. L., MOURÃo, C. A., AND PÉREz-SALAs, s. 1972. Enzyme variability in the Drosophila willistoni group. IV. Genic variation in natural populations of Drosophila willistoni. Genetics, 70, 113-139.

BARNES, B. W., AND KEARSEY, M. J. 1970. Variation for metrical characters in Drosophila populations. I. Genetic analysis. Heredity, 25, 1-10.

Grbson, J. 1970. Enzyme flexibility in Drosophila melanogaster. Nature, 227, 959-960.

GIBson, J., AND MIKLOVICH, R. 1971. Modes of variation in alcohol dehydrogenase in Drosophila melanogaster. Experientia, 27, 99-100.

Harris, H. 1966. Enzyme polymorphisms in man. Proc. Roy. Soc., B, 164, 298-310.

HARRIS, H. 1969. Enzyme and protein polymorphism in human populations. British Medical Bulletin, 25, 5-13.

HARRIS, H. 1971. Polymorphism and protein evolution. The neutral mutation-random drift hypothesis. Fournal of Medical Genetics, 8, 444-452.

HUBBY, J. L., AND LEWONTIN, R. C. 1966. A molecular approach to the study of genic heterozygosity in natural populations. I. The number of alleles at different loci in Drosophila pseudoobscura. Genetics, 54, 577-594.

LEWONTIN, R. C., AND HUBBY, J. L. 1966. A molecular approach to the study of genic heterozygosity in natural populations. II. Amount of variation and degree of heterozygosity in natural populations of Drosophila pseudoobscura. Genetics, 54, 595-609.

MILler, G. L. 1959. Protein determination for large numbers of samples. Anal. Chem., 31, 964.

SELANDER, R. K., AND YANG, s. y. 1969. Protein polymorphism and genic heterozygosity in a wild population of the house mouse (Mus musculus). Genetics, 63, 653-667.

PouLIK, M. D. 1957. Starch gel electrophoresis in a discontinuous system of buffers. Nature, $180,1477-1479$.

WARD, R. D., AND HEBERT, P. D. N. 1972. Variability of alcohol dehydrogenase activity in a natural population of Drosophila melanogaster. Nature New Biology, 236, 243-244. 